\title{
Urgences
}

\section{Un appel...}

\section{Hélène Chassé}

Numéro 29, octobre 1990

\section{Éclats d'œuvre}

URI : https://id.erudit.org/iderudit/025610ar

DOI : https://doi.org/10.7202/025610ar

Aller au sommaire du numéro

\section{Éditeur(s)}

Urgences

\section{ISSN}

0226-9554 (imprimé)

1927-3924 (numérique)

Découvrir la revue

\section{Citer ce document}

Chassé, H. (1990). Un appel... Urgences, (29), 74-74.

https://doi.org/10.7202/025610ar d'utilisation que vous pouvez consulter en ligne.

https://apropos.erudit.org/fr/usagers/politique-dutilisation/ 
IMPRÉVUS 


\section{Hélène Chassé}

Un appel irrésistible de l'encre et du papier. Un écran vierge d'ordinateur sur lequel fumée de cigarette et doigts en suspens feront naître le mot, la phrase. Ces paragraphes du besoin de dire, au-delà de soi, dans le creux de soi, sans traîtrise et condescendance. Un livre chaud fermé. Un allegro de Cimarosa. Un regard, une vie du moment ou de tout le temps. Sens en émoi. Recherche esthétique du verbe. À ne pas taire. Absolument. 